\title{
Impact of Innovation and Places on Corporate Governance the Case of Wind Turbine Production
}

\author{
Jan Gunnarsson*, Nikola Cikusa and Anca D. Hansen \\ University of Copenhagen, Department of Economics \\ Technical University of Denmark, Department of Wind Energy \\ Email: jg@econ.ku.dk
}

\begin{abstract}
We examine how corporate governance changes over the industrial life cycle when places commit firms to certain governance structures. Focus is on industries where a significant part of the economic value is created by technological knowledge changing the conditions for corporate financing. The article extends this view to include knowledge needed to accumulate governance capabilities. The board is a crucial governance institution emphasized in the study. We find that changes in this institution depend on shareholders' concern regarding innovation management. We also find that boards are changed over time to improve the conversational exchange, which is attained by extending the boards with directors holding degrees in engineering. The main finding is that the most successful firms recruit board members from the geographic setting in which they were founded at all stages of the industrial life cycle. The Danish wind turbine industry serves as empirical evidence.
\end{abstract}

Keywords: Corporate governance, board, industrial life cycle, firm-specific knowledge, geographic place.

\section{Introduction}

The history of a company is tied to a certain place. This has been recognized by geographers who raise the question regarding "the placement of firms", suggesting that geographic settings produce different types of firms (Dicken 2000). This is particularly evident when looking beyond large adolescent firms. Properties of places where firms are founded influence the accumulation of knowledge which make them grow into competitive firms. The view of a place as a corporate reservoir of technological knowledge needs to be extended to knowledge needed to accumulate governance capabilities. This article aims to examine changes in corporate governance over time when properties of the geographic location commit companies to certain governance structures. The relatively under-researched knowledge dimension is the lens through which we look at ties between governance, places, and time. The share of human capital is significant in most companies and the replacement of physical capital by its human counterpart implies a qualitative change in corporate financing that has triggered scholarly discussions about the appropriateness of the shareholder value model that stresses the accountability perspective on corporate governance (monitoring and control) (Rajan \& Zingales 2000). In writing this article, we have been inspired by Short et al. (1999) and Filatotchev and Wright (2005) who move the corporate governance focus away from the accountability perspective by suggesting approaches that encompass the enterprise aspects of governance. Before investing in a company, owners and investors carefully deliberate the business value that is derived from the development of the internal resources and the growth potential.

In particular, we look into consequences of the geographic setting for understanding the enterprise aspects of governance. It can be referred to scholars researching how corporate governance varies between countries depending on national systems. A majority of these scholars apply the accountability perspective and highlight how the protection of shareholders by a country's legal system influences corporate governance (La Porta et. al. 2000; La Porta et. al. 1999). Others apply a slightly different perspective addressing the embedments of governance in national systems when shareholders take active part in formulating corporate strategies. Kogut and Walker (2001) enquire into the German system characterized by ownership links between firms combining to form "small worlds" of stratigizing actors that emerge from regional networks with local banks playing an important role. The authors find that the "small worlds" 
are robust to adjustments to remain competitive and resist global economic pressures. In the same vein, Kogut (2012) argues that the national systems emerge from micro-behavior. This behavior is guided by particular generating rules that derive from social relations between investors and entrepreneurs, who can formally be bound through boards of directors. Even if national systems remain, there is plasticity in the governance structure as technological templates influence strategic actions (Kogut \& Walker 2001). These structures are formed by rules that tend to attract and select board members with higher education. According to Kogut (2012), there are also multiple studies showing that the recruitment is conditioned by homophily, i.e. a tendency for people to have ties with people who are similar to themselves in socially significant ways. Homophily is often associated with people living together in the same place, usually in smaller places than countries. In this article, we examine in depth how governance structures emerge when investors and entrepreneurs are geographically fragmented.

Although researchers have inquired into changes in corporate governance when actors are strategizing, changes have followed the organizational life cycle (Clark 2007; Zahra \& Hayton 2005; Filatotchev \& Wright 2005). Research has mostly neglected the critical topic of industry dynamics and how the evolution of governance is connected with technological competition in single sectors. This article tries to fill this gap. The way competition within industries evolves over time, as expressed by the industrial life cycle, becomes central to our exploratory activities (Yamamora \& Sonobe \& Outsaka 2005), (Klepper 1996), (Cohen \& Klepper 1992), (Gort \& Klepper 1982). We argue that competition within an industry is mastered by innovation management, and corporate governance is shaped by financiers' concern about innovation. In addition, more researches are needed to address the influence the location of corporate activity has on the governing of innovation management. Significant research addresses the importance of specific geographic places as sources of core competencies needed for firms' competitive performance (Werker \& Athreye 2004; Asheim \& Gertler 2006). Research also shows how corporate governance is improved if residents, where a company attracts and generates knowledge, are invited to the boardrooms (Bottazzi, Da Rin \& Hellmann 2009; Audretsch, Keilbach \& Lehmann 2006). Yet, more researches are needed regarding consequences of governance in companies that depend on places when managing their competitive situation. This article tries to make a contribution to this under-researched area.

The corporate governance system includes a wide range of institutions such as the board of directors, ownership structures, formal institutions for judicial power, and governance institutions that safeguard a reliable and transparent accountancy. The point of departure of this article is that the control rights are allocated to the shareholders. This allocation of the residual control rights can rightly be questioned (cf. Aglietta \& Rebérioux 2005). In stretching the interpretation of this control, we link up with the team production theory of the firm that makes efficient governance systems synonymous with the protection of the interests of all stakeholders that invest in the core competencies of a company (Machold et. al. 2011), (Huse \& Gabrielsson 2008), (Blair 1998). Further, the board of directors has a critical function as mediator between a firm's value-adding stakeholders. As Huse and Gabrielsson (2008) show board members' involvement in the strategic decision making process becomes crucial for corporate innovation. While the board also is a vital corporate governance institution, we choose the board of directors as indicator of the state of corporate governance (dependent variable). However, the research has mostly ignored how boards of directors are adjusted to accommodate changes when the industrial life cycle proceeds from one competitive stage to another, and when properties of geographic places have an impact. The present article tries to fill this gap.

We use a single-case study of wind turbine production to inductively propound propositions and ideas that push forward extant theories about relationships between geographic places, technological competition and corporate governance (boards). Since the purpose is to develop theory, not to test it, large-sample evidence to run proper statistical analyses is not needed. By choosing an industry characterized by intense technological competition, we have sampled a case particularly suitable for illuminating and extending the relationships examined in the study. Although previous studies have used buyouts as empirical evidence to inquire into investors' concern about innovation management, the consequences for governance have been of less frequent inquiry. Lerner et. al. (2008) find that after certain types of buyout, such as private equity investments, firms pursue more economically important innovations as measured by patent citations. Hellmann and Puri (2000) point out that venture capital involvement leads to a shorter time for a firm to bring a product to the market, and firms pursuing an innovator strategy instead of an imitator strategy 
are more likely to obtain venture capital financing. Likewise, Zahra and Hayton (2005) find that R\&D investments are positively associated with venture capitalist involvement at the start-up stage of a firm.

This inductive case study has the ability to offer insights into the complex patterns of responses by new governance structures in connection with buyouts, which theory-testing cannot easily reveal. It is reported to develop a richer understanding of how changes in board institutions are linked to shareholders' concern about changes in competition over the industrial life cycle. A question that arises is if the most successful firms assign high values to board members' geographic proximity to firm-specific knowledge and recruit board members from the geographic setting in which the firms were founded. Section 2 is devoted to a survey of our point of conceptual departure. After a discussion about scientific methods, research context and data in section 3 , section 4 is devoted to the presentation of our analyses and results, while section 5 is a discussion about the results and sums up our main conclusions.

\section{A Brief Survey of Problems}

\section{The industrial life cycle}

The internal structure of national systems of corporate governance reflects historical bargain between labor, the state and holders of capital regarding the structuring of the financing and governance of large corporations (Kogut \& Walker 2001). The systems are sectorially fragmented, besides being regionally fragmented. When industries are new, entry is massive. Competition focuses on product innovation as many firms offering different product variants enter the market. Since the producers constantly learn how to improve the products, the number of product opportunities erodes, entry slows, and exit overtakes entry. Meanwhile, a dominant design and routinized technological regime appear (Klepper 1996). When an industry is young and still complies with an entrepreneurial technological regime external shareholders face severe difficulties in assessing the proper value of companies. Steps to obtain more accurate information about the business value can effect the type of governance. While the calculation of the commercial risk is made by the investor, there is usually a close connection between the founder and the CEO (sometimes the same person) and in Reid's and Smith's wording "they may feel they know they have the best scientist, the best invention, the best new product design, but they do not know how to value this" (Reid \& Smith 2008 p. 30). At later stages of the industrial life cycle, the prominence of one dominant design facilitates the assessment of business values.

Competition is intensified over the industrial life cycle. Intensified competition is caused by the appearance of a dominant design, which implies that the potential market for a distinct company increases. Increased firm growth increases the demand for financing, which cannot be satisfied without changes in the ownership structure. Corporate control moves from insiders to external investors (see Clark 2007) and corporate governance changes from pursuing enterprise aspects to an accountability perspective (Short et al. 1999), (Filatotchev \& Wright 2005). Yet, it seems as if existing research does not address changes in governance to the extent they deserve. For instance, the transition to the routinized technological regime implies a change in the knowledge conditions of technology as the importance of accumulated non-transferable market experience increases. Firms entering a market cannot possess this experience (Audretsch \& Fritsch 2002). In other words, and as already mentioned, this transition facilitates calculations of the economic value of investments in new technology, which is an advantage for external investors, who rely on financial accounts and financial evaluations of a business. However, the possibility of letting outsiders share internally accumulated market experience, and to transact knowledge about the economic value of internal intangible assets, is limited. Transfers of corporate control to external directors are restricted at later stages of the industrial life cycle as it is necessary to take competition interests into consideration. Due to competitive pressure, provision of information in financial accounts is circumscribed by the sensitivity of the value of trade secrecy. Reid and Smith (2008) conclude that disclosure in published accounts could be seen as providing too much information to rivals.

This survey hints that governance by outside discipline and monitoring by investors and owners is not always efficient. Allen and Gale (1998) find that there are firms that compete efficiently in international markets and conclude that firms can generate return for shareholders even if standard corporate governance mechanisms are inefficient. Their explanation is the dynamic competition in product markets where firms survive competition because of entrepreneurial management teams that do more than cost minimize or act as stand-ins for shareholders. It is reasonable to conclude that there is a lack of viable theory and of 
empirical evidence of how governance changes over the industrial life cycle. In this article, we argue, and illustrate empirically, that there is more in this topic than just a matter of changing corporate governance from enterprise aspects to compliance with the accountability perspective at later stages of the cycle.

The knowledge dimension and business value

For industries with a high rate of human capital accumulation, Rajan and Zingales find a new task to be performed by the directors: "to protect its /the company's/ integrity" (2000, p. 222). Human capital is more mobile than physical capital implying that the corporate governance system loses power, and the entity being governed becomes indistinct. Audretsch (1995) and Toms and Filatotchev (2005) associate this task with conflicts concerning strategies. We argue that the evolution of corporate governance depends on how the task to protect the integrity is performed and agree with Short et al. (1999) and Filatotchev and Wright (2005) that scholars usually overstate the task to monitor management. In doing that, they neglect shareholders' concern regarding the business value deriving from the control over internal knowledge assets and the company growth potential.

Scholars sometimes argue that a company's principal knowledge assets are created early and is difficult to change afterwards (Kaplan et. al. 2009), (Klepper 1996), (Cohen \& Klepper 1992). If this argument is correct, concern for the enterprise aspects should be concentrated on the early stage of the industrial life cycle. However, inquiries into the motorcycle industry in Japan show that the number of qualitative improvements of the product increases at later stages of the life cycle (Yamamora \& Sonobe \& Outsaka 2005). Studies of the machine tool industry in Taiwan and the motorcycle industry in Germany and in the UK show similar results. Gort and Klepper (1982), on the other hand, find that output of useful innovations by US producers of new products increases at the early stages of the life cycle and decreases subsequently. Contrary to Cohen and Klepper (1992), some scholars argue that expertise is not acquired randomly but is deliberately extended. Companies investing in R\&D increase the information about innovative opportunities as well as the capability to absorb this type of information. Through boosting the supply of innovative opportunities, investments in R\&D will be further increased by incentives to invest in absorptive capability; especially at later stages of the industrial life cycle when the supply is large (Cohen \& Levinthal 1989).

Existing theory does neither offer a satisfactory answer to the question of when companies' knowledge assets are created nor how the performance of the integrity task causes changes in governance over time. This article tries to make a contribution to the theory by looking into how governance responds when the type of conflict about technology varies over the stages of the industrial life cycle. Audretsch (1995) argues that technological capability is lost at the early stage of the industrial life cycle, owing to the fact that the corporate governance system is unable to settle conflicts about innovation management. These conflicts concerning the value of innovations give employees with new ideas an incentive to leave and set up their own firms. At later stages of the cycle, where firms compete in accumulating firm-specific knowledge, it is difficult to create governance systems that can protect the financiers from knowledge leakage caused by the mobility of qualified employees (Rajan \& Zingales 2000), (Zingales 2000), (Estevevez-Abe, Iversen \& Soskice 2001). Altogether, these conflicts reduce the business value of investments, which requires remedial action to reform governance.

Boards of directors

Research about the role of boards for managing companies' integrity has the potential of being integrated into a theory of timely changes in corporate governance. The team production theory looks promising (Machold et. al. 2011), (Blair 1998). It views the firm as a nexus of team-specific assets invested by various stakeholders, who profit from team production. Instead of contracting with each other about shares in team production, team members transfer decision-making about duties and rewards to a "mediating hierarchy" (Machold et. al. 2011 p 370). In real firms, this function is performed by the board, which is a team that co-produces values, where the board members contribute with different knowledge and skills. To sustain authority over valuable resources, boards build complementarities: links with which the employees and the company can create more value together "...than they can by going their own separate ways" (Rajan \& Zingales 2000 p. 215). Employee ownership can incentivize the employees to invest in firm-specific skills. Likewise, complementarities are created if skilled workers are offered stock options and shares.

Becker (1964) argues that companies that pay marginally above the market wage for the employee's marketable skill pay fully for the company-specific skill, and the shareholders therefore appropriate the 
full return on the investments. As Estevez-Abe, Iversen and Soskice (2001) point out, the acquisition of firm-specific knowledge implies that the employees' marketable skills may deteriorate if not used and they will not be upgraded at the same rate as among the employees who practise them daily. We argue that compensation for increased risk, when the marketable skills deteriorate, is necessary to consolidate the long term growth potential of a company. Yet, this does not generally serve short term shareholder interests, but a board acting as a "mediating hierarchy" is needed. Blair (1998) concludes that the board of directors and the management are responsible for maximizing the wealth-creating potential of companies. The employees are much more motivated to find new ways to innovate or cut costs if they know that managers and directors listen to them. Likewise, Huse and Gabrielsson (2008) argue that the interests of all stakeholders that make up the core competencies of the corporation should be protected and the board of directors is a critical coordinating body that represents and mediates between all the stakeholders who add value.

Blair (1998), Huse and Gabrielsen (2008) and Machold et. al. (2011) convince us that focusing on boards can provide significant insights into our research questions. They concentrate on properties boards must have to encourage all value-creating stakeholders to stay in a company and create more value. Firstly, the board members should deliberately influence corporate innovations by getting involved in strategic decision-making processes. Secondly, they should comply with a process-oriented boardroom culture based on "discussions related to diverse knowledge inputs and the existence of potential opposing view points, and where the boards represent a diverse set of stakeholders in and around the firm" (Huse \& Gabrielsson 2008, p. 8). However, the way board properties, that denote the state of corporate governance, are adjusted to the need for developing growth opportunities that changes with the competitive stages of the industrial life cycle has been the subject of less frequent inquiry. The ignorance of this topic is critical as research reveals that the conditions for communicative exchange at the boards depend on type of technological regime. This regime changes over the life cycle with significant consequences for the dialogues in the boardrooms as well as for the dialogues with the stakeholders in- and outside the companies.

Impact of places

A plausible theory is lacking in how governing the development of growth opportunities through the industrial life cycle depends on ties that the companies' value-creating stakeholders have to a geographic place. Existing theories have usually highlighted corporate governance performance in national systems without considering spatial decomposition into smaller geographic units than countries (see Kogut 2012, Kogut \& Walker 2001, La Porta et. al. 2000; La Porta et. al. 1999). A Scandinavian study of governance uncovers networks of highly connected directors, but theory and empirical evidence exploring how the recruitment of business groups is conditioned by homophily inside geographic spaces are lacking (Sinani et al. 2008). Studies of financial market development suggest that venture capital formation is a highly localized activity, and investing at a distance is something venture capitalists tend to avoid (Bottazzi, Da Rin \& Hellmann 2009). The authors do not raise the question about which type of quality the board directors must have to express the perspectives of the different value-creating stakeholders, when the stakeholders are more or less tied up to a geographic place.

Short et al. (1999) conclude that outside directors may ignore the enterprise aspects of governance. Inside directors are more inclined to promote innovation strategies based on internal technological competencies. We try to argue that they, for the most part, are recruited from the place, where the company generates and attracts technological knowledge. They are able to interpret information regarding technology that is difficult to assess in a financial sense. Zahra and Hayton (2005) report that a high share of inside directors is conductive to high R\&D spending and new product introduction. Outside directors serving on the board have no significant effect on innovative performance. Representation in the boardroom of the founders of a company also encourages innovative performance. They understand the need to support R\&D as a means of creating value. The functional and educational diversity of board members also turn out to enhance innovation.

Previous discussions suggest that enterprise aspects are crucial during early stages of the industrial life cycle. The entrepreneurial technological regime makes it difficult to asses proper values to companies. It is reason, therefore, to believe that outside directors are disqualified and board directors should be more or less tied up to places, where a company creates and absorbs its technological knowledge. Inside directors are also needed in the boards at later stages of the cycle. They are capable of motivating the value-creating 
stakeholders to stay in a company and create more value as they usually live in the same place and belong to the same social and professional communities. Inside directors make up teams (together with managements) that can take advantage of agglomeration factors such as concentrations of place-based knowledge that is immobile over long distances. Externalities that assume the shape of knowledge spillover are present and imply that firm-specific knowledge is not used by one firm, but it is also used by other firms within a region (Werker \& Athreye 2004; Asheim \& Gertler 2006). Knowledge spillover is common at late stages of thew cycle and derives from employees who personify the knowledge and move between working places in a regional labour market (Fosfuri \& Rønde 2004). Knowledge creating firms, benefiting from being located in close proximity to communities with research output, improve their governance by inviting members of these communities into their boardrooms (Audretsch, Keilbach \& Lehmann 2006).

Human capital is more mobile than physical capital and the migration of skilled employees is sometimes a sign that corporate governance systems have lost power. Technological externalities make the definition of the value adding stakeholders blurry with implications for the work in the boardroom. The mobility of human capital increases in clusters, while peoples' unwillingness to move over long distances prevents technology from diffusing out of a cluster (cf. Brenner \& Fornahl 2008). Consequently, the maximization of the total wealth-creating potential of the enterprises becomes increasingly difficult. Audretsch (1995) points out that skilled workers leave because of an inability of the board and the CEO to assess the value of new ideas. Assessments would likely become more efficient with inside, place-based directors, who have firm-specific knowledge.

\section{Data and Method}

With the aim to develop theory regarding changes in corporate governance compelled by the geographic location, we use inductive reasoning applied to a longitudinal case study. This method is appropriate for theory building (Eisenhardt \& Graebner 2007). Since the research tries to push extant theory forward, not to test existing theory, this method enables us to select a case that is particularly suitable for illuminating and extending relationships and logic among constructs. If chosen with care, a case study serves the purpose of our study, because it enables us to use rich empirical data from close investigations of buyouts and their impact on boards. Like what other scholars using cases for theory building have done before us, we started our study by collecting data from which we develop theory inductively (see for instance Khanagha et. al. 2013). An industry producing with new technology - Danish wind turbine production was chosen as our case. Multiple sources of information were used such as documents provided by an acknowledged consultant firm specialized in the provision of information about the wind energy sector ${ }^{1}$. Supplementary information was obtained from the pan European data-base Amadeus, and from EU's research and development service Cordis.

In line with other researchers, we interpreted data and theory iteratively by initiating studies of literature on corporate governance in companies, where the share of human capital is high. It was evident that the literature had ignored critical topics about human capital, especially what human capital implies for the interrelationships between governance and characteristics of places. This encouraged us to continue and after each round of data collection and analysis, we returned to the literature and made new interpretations in the light of the extant theory. In practice our results are based on a single-case study. This makes our theory building less generalizable, but at the same time a single-case study is unusually revelatory (cf. Eisenhardt \& Graebner 2007)

This approach gives us the opportunity to describe buyouts and their impacts in depth. Data on Danish wind turbine producers have been collected from various sources for the years 1979-2008, which has simplified the empirical analysis as it enables us to make use of quantitative measures. To further improve the empirical analysis, we also use interviews with board members and, thus, gain from combining quantitative and qualitative methods. Neither method is superior to the other. Rather they are seen as providing complementary data, where interviews with board members have been indispensable for making a historical record of the buyouts, for convincing us about the importance of innovation management for financiers investing in companies and for getting insights into conversations at the boards. For the quantitative method, information regarding board members (by company), was gathered from the Central

${ }^{1}$ The Danish consultancy company BTM Consult 
Business Register (CVR) at the Danish Commerce and Companies Agency ${ }^{2}$. Information regarding ownership status was obtained from the same register where all stakes equal to, or larger than, $5 \%$ are registered. The educational background of the board members and their home addresses were obtained from bibliographies ("Kraks Blå Bog") and from a questionnaire completed by a sample of directors, who have been members of the various boards considered in the study. By this procedure it was possible to identify board members by residence and by educational background either in natural sciences and engineering or in economics (including business administration) and law ${ }^{3}$. Further, it was possible to determine whether a member has completed upper secondary school or a university degree as his or her top form. These and only these data are used in the case-study in the article

Corporate technological quality can be associated with the amount of technological expertise in a company. Data on the number of employees holding a university degree in engineering or natural sciences are obtained from Statistics Denmark for the whole lifetime of all wind turbine producers examined. It is not satisfactory to use input of skilled labor as the sole measure of technological quality. Accordingly, these data are used only to a small extent and never in conclusions about case studies of individual companies. They only enter into overall conclusions about how all turbine manufacturers examined usually adjust skilled labor in connection with buyouts (section 4.2) and how board structures are adapted to these adjustments (section 4.3). Thus, a second measure of technological quality is applied based on types of turbines produced by the companies. This is accomplished as wind turbine designs are categorized into four main concepts based on publicly available data from each manufacturer according to principles discussed below.

We have made a point of validating data through cross verification from various sources. Firstly, we have combined documents, official statistics and interviews with board members involved at different stages of the industrial life cycle. Secondly, information obtained, and results achieved, have continuously been controlled for reasonableness with staff members of an acknowledged consultant firm specialized in the provision of information about the wind energy sector ${ }^{4}$.

\subsection{Case Selection}

In admitting that the technological competition, which fluctuates through the industrial life cycle, influences the answers to the research questions, we anchor the case study at the industry rather than the firm level. By our decision to study an industry brimming with technological competition, we have sampled a case particularly suitable for examining the research questions. For the purpose of taking a long view, it was important that the industrial life cycle had already reached the late stage to assure that changes in corporate governance institutions and in the technological quality of the firms have a recorded history. Wind turbine production, which developed in the wake of the oil supply crisis in the 1970s, is appropriate for this purpose. Another advantage of choosing this industry was that we could limit data-collection to a group of Danish wind turbine producers. Denmark was the pioneering country, and Danish turbine producers still have large market shares. This choice of industry also serves our purpose to examine how properties of places affect corporate governance as the Danish production of wind turbines is geographically concentrated to a region in Jutland, West Denmark. That is to say, geography plays a role in the evolution of the Danish wind turbine industry and an examination of this industry may reveal significant mechanisms through which geography influences on corporate governance.

Historical data about buyouts, boards, and the domicile of the directors have been collected for a sample of turbine producers, which, however, includes the major Danish producers through time (table 1). Since these producers shaped the industry during this time, our data reflect changes in the state of competition in a timely manner. Table 1 shows that a major part of the producers in the sample has left the market either through M\&A or by market exit, and there are only two companies left: Vestas Wind Systems and Siemens Wind Power. It is also shown in the table how current firms, and firms that exit, stepwise are shaped by M\&A.

There are different ways of measuring success of a business. All firms in table 1 have not been successful as some have either exited or been taken over by other turbine producers. In the paper, we try to argue

\footnotetext{
${ }^{2}$ Erhvervs- og Selskabsstyrelsen

${ }^{3}$ In addition, there were a few board members, who were classified as "others"

${ }^{4}$ The Danish consultancy company BTM Consult
} 
Table 1. Danish producers of wind turbines examined in the article.

\begin{tabular}{llll}
\hline Current firms & M\&A & Lifetime & Nr. \\
Vestas/Vestas Wind Systems & & $1979-$ & $1-2$ \\
& Danish Wind Technology & $1981-1990$ & 3 \\
& NEG-Micon & $1997-2004$ & 4 \\
& Micon & $1983-1997$ & 5 \\
& Nordtank/Nordtank & & \\
& Energy Group & $1979-1997$ & $6-7$ \\
Siemens Wind Power & Wind World & $1987-1998$ & 8 \\
& & $2004-$ & 9 \\
Exits from the market & Bonus Energi & $1979-2004$ & 10 \\
Wincon West Wind (A/S Vestfrost) & & & 11 \\
& & $1991-2002$ & 12 \\
\hline
\end{tabular}

Sources: BTM Consult and web sources

that organizing the control according to the shareholder value model is not necessarily successful. Control by owners should also encompass consideration about the growth potential and technological competition orchestrated through innovation management to be successful.

Technological competition

The amount of technological expertise is not the sole measure of corporate technological quality. A second measure applied is based on pioneering work done to classify turbine models according to two characteristics: the speed control ability and the power control ability of the turbines (Hansen \& Hansen 2006). The market penetration of different wind turbine concepts is strongly influenced by the wind turbines control abilities, i.e. by their capabilities to behave as active controllable components on the grid.

The most commonly applied wind turbine concepts, also depicting the technological quality of the turbine producers, can be categorized into four main types (table 2). Type A denotes the fixed speed controlled wind turbine, which is the conventional concept applied by many Danish wind turbine manufacturers during the 1980s and 1990s. Besides an induction generator, the electrical system of fixed speed wind turbines contains a soft-starter for smoother grid connection and a capacitor bank for reactive power compensation. This concept has been very popular because of its relatively low price, its simplicity and its robustness. Its disadvantages are mechanical stress, limited power quality control and un-controllability of reactive power consumption. Type B corresponds to the limited variable speed controlled wind turbine with variable generator rotor resistance, known as OptiSlip ${ }^{\circledR}$ or FlexiSlip ${ }^{\circledR}$.

The idea of this concept is that it uses a wound rotor induction generator (WRIG) with a variable additional rotor resistance which is controlled optically and changed dynamically by power electronics. This type of wind turbine was promoted by Vestas Wind Systems since the mid 1990's up to 2006. The advantages of this concept compared to type A are a simple circuit topology and an improved operating speed range. To a certain extent, this concept can reduce the mechanical loads and power fluctuations caused by gusts. Some of the disadvantages are limited speed range and poor control of active and reactive power.

Type $\mathrm{C}$ denotes the variable speed wind turbine concept with double-fed induction generator. It uses a partial-scale power converter connected to the generator's rotor typically through slip rings. The stator is directly connected to the grid, while the rotor is connected through a partial-scale power converter. This concept is more expensive than type $\mathrm{A}$ and type $\mathrm{B}$, but it has a wider range of dynamic speed control depending on the size of the power converter. The partial-scale converter makes this concept 
Table 2. Year of first time application of wind turbine concepts by producers.

\begin{tabular}{lccc}
\hline Producer & Lifetime & Technology & First time application \\
\hline Vestas/Vestas Wind Systems & $1979-$ & Type A & 1981 \\
& & Type B & 1990 \\
& & Type C & 1997 \\
Bonus Energi & $1979-2004$ & Type A & 1981 \\
Nordtank/Nordtank Energy Group & $1979-1997$ & Type A & 1981 \\
Danish Wind Technology & $1981-1990$ & Type A & 1981 \\
Micon & $1983-1997$ & Type A & 1983 \\
Danwin & $1985-1992$ & Type A & 1985 \\
Wincon & $1986-1991$ & Type A & 1986 \\
Wind World & $1987-1998$ & Type A & 1987 \\
Wincon West Wind & $1991-2002$ & Type A & 1991 \\
NEG-Micon & $1997-2004$ & Type A & 1997 \\
& & Type C & 2002 \\
Siemens Wind Power & $2004-$ & Type A & 2004 \\
& & Type D & 2004 \\
\hline
\end{tabular}

Source: Publicly available data on the newest wind turbines from each manufacturer

attractive from an economical point of view. Finally, type D corresponds to the full variable speed pitch controlled wind turbine, with the generator connected to the grid through a full-scale power converter. The presence of the full-scale converter implies extra losses in the power conversion, but it is gained by the added technical performance. This concept has full control of the speed range from 0 to $100 \%$ of the synchronous speed. It supports reactive power compensation and a smooth grid connection. However, it has a higher cost and a higher power loss in the power electronic than Type $\mathrm{C}$ as all the generated power has to pass through the power converter.

\subsection{Measures of Governance}

This article searches to explore how boards are adjusted, but it needs a measure of how this corporate governance institution changes over the industrial life cycle. It is argued that changes are conditioned on companies' need of growing knowledge assets. Literature in the field of team production theory connects this condition with a process-oriented boardroom culture, where boards give advice to CEO (Huse \& Gabrielsson 2008). One question arising is which types of board member are suitable for this kind of board culture. Fama and Jensen (1983) argue that a majority of the board directors should be independent, but a review of literature suggests that no systematic relationship between independence of boards and performance can be found (cf. Johnson et. al. 2012) Instead, Johnson et. al call attention to a growing body of research about board members' demographics, human and social capital. Like Zahra and Hayton (2005) they find that director education, which is highly correlated with human and social capital, affects innovative performance and, thus, should be included in our measure of changes in governance. However, a process-oriented boardroom culture can be more or less useful for corporate innovations depending on the conversational exchange, which concerns the board work as a whole. It is referred to Johnson et. al. (2012), who caution against overlooking that board composition is endogenous and determined by how various subgroups of directors can contribute to this conversation and influence on firm outcome. From this perspective, it becomes dubious to use aggregate units such as educational level. A more adequate approach looks at various educational groups at the board and if there are critical thresholds with regard to representation below which individual groups will have no influence. A similar approach was applied in a study in the UK, where Kirchmaier and Kollo (2006) find that professional directors are 
most likely to hold business degrees. Yet, as Kaufman and Englander (2005) argue, boards that maximize the wealth-creating potential are comprised by directors, who can knowledgeably express the interests, perspectives, and expertise of all value adding stakeholders. This viewpoint has been taken on board as board members educated in natural sciences or engineering, who can speak for the skilled technicians, are included in our governance measure (besides directors with an education in economics).

We measure the evolution of governance over the industrial life cycle using four board structures. Firstly, these structures are based on information about the number of board members and their educational background and, secondly, on conjectures about subgroup effects on board performance: Type A educational diversity - refers to boards that have at least one director with an educational background in the natural sciences or engineering and at least one director with an educational background in economics (including business administration) or law. If there is only one director with a particular educational background on the board, his/her field of knowledge may not be considered by other board members. Type B - symmetry of the conversational exchange - takes better account of subgroup effects by including more than one director with a particular educational background. For boards with more than six members, at least three must have an education in the natural sciences or engineering and at least three directors must have an education in economics (including business administration) or law. If a board has six or less members, two members for each group are sufficient. Learning among board members also depends on educational specialization in the dimension of sophistication. Moderately specialized boards that combine directors with high levels of education and directors with practical education within the same fields are considered as preferable. A board is moderately specialized (type $C$ ) if there are two or more members on the board who are educated in the natural sciences or engineering and two or more with an education in economics (including business administration) or law. For each group, at least one director must have completed upper secondary school as his or her top form and at least one director must have a university degree.

These board structures can be arranged in a perfect hierarchy, used in this article to assess board performance: boards of type B are superior to boards of type A as the conversational exchange in the boardroom is not only symmetric, but the boardroom is also educationally diversified. Likewise, a board structure of type $\mathrm{C}$ is superior to type $\mathrm{B}$, as a moderately specialized board also allows for symmetric conversational exchange. However, for boards with more than six members, a perfect hierarchy exists only if there is a requirement for three board members (instead of two) of each educational group in the type C structure. This typology of structures does not suit the smallest boards. Small boards (type D), with less than four members, will be examined separately.

This article also needs a measure that relates board work to geographic places. We argue that corporate governance is improved if board members are recruited in the same region as a company has its main sources of technological knowledge and, therefore, it makes sense to distinguish between these directors and board members recruited in other regions. We support the idea that the first type of director has capability to express the perspectives of the different value-creating stakeholders, who are more or less linked to a company's home base. Probably, this geographical composition of boards is helped by homophily found in multiple studies of board recruitment (cf. Kogut 2012). One question arising is if the need of place-based directors changes over the stages of the industrial life cycle. In order to answer this question empirically, we construct a measure of how investors searching corporate control assess directors recruited near to the company home base as compared with directors recruited from remote places. We use a measure $\frac{D_{1}}{D_{2}}$ to indicate how those in control of a company assess the geographical distance between board directors $\left(D_{1}\right)$ as compared with board directors' distance to the place, where the company generates and attracts technological knowledge $\left(D_{2}\right)$. More specifically, $D_{1}$ is equal to the average distance between the directors' residences and the geographic centre of the residences and $D_{2}$ is equal to the distance between the geographic centre of the residences and the location of the headquarter of the company.

\section{Analysis and Results}

\subsection{Buyouts}

We started our case study by making historical records of the buyouts for each turbine manufacturer in table 1 . These records present the history of our case that offers opportunities to examine in depth 
investors' reason for buyouts as well as adjustments in governance. Starting in 1946 as a manufacturer of products for farming and domestic appliances, the founder of Vestas, who was a son of a well-known local blacksmith, bought the rights to produce "Herborg-møllen" (the HVK turbine) in 1979. Vestas was a family-owned company until it was hit by a crisis in 1986. Changes in governance were initiated by a small group of people who knew one another, including a member of the founding family. These managers and financiers carried out a management buyout, sold some businesses, and transferred the manufacturing of turbines to a new company: Vestas Wind Systems. Before, another manufacturer, Danish Wind Technology, was established by the Danish government, the Danish company Vølund and Swedish ASEA in 1981. At the time for the management buyout of Vestas, the Danish government sold its stake in Danish Wind Technology and Vestas Wind Systems, together with a utility company (SEAS), became new owners of the company. The utility and a Danish pension fund (Lønmodtagernes Dyrtidsfond) also bought stakes in Vestas Wind System in 1989 and the stage was prepared for the takeover of Danish Wind Technology by Vestas Energy Systems through a buyout in 1990. In 1994, when the original owners began to sell their stakes, a new group of mainly Dutch investors began to grow in importance ${ }^{5}$. Vestas Wind Systems was introduced on the Copenhagen Stock Exchange in 1998 and the Dutch block holders left in 1999.

Nordtank (established in 1979) is an offspring of a company producing tank lorries, and the main part of its shares was controlled by the two founding fathers until it was stuck in a crisis in 1987. A management buyout was carried out, but no dramatic change in the governance seems to have taken place until the company was publicly traded at the Copenhagen stock exchange in 1994. It changed its name to Nordtank Energy Group in 1987. Nordtank was the point of departure for a spin-off organized by two engineers who set up Micon in 1983. A conflict between the two in 1986 led to Micon being split up into two companies (Wincon and Wenergy). Wincon went through a couple of crises and a buyout in 1991 transferred the control over the company to a leading Danish producer of household appliances (A/S Vestfrost) and it was renamed Wincon West Wind. The constellation of owners was the same throughout the whole lifetime of Wincon West Wind which closed down in 2002.

The second engineer set up Wenergy which was renamed Micon in 1987. Before going out of business in 1992, he tried to establish new leadership involving one of the world-leading contractors and operators of medium and large diesel engine based power systems (Burmeister \& Wain) which became a block holder in 1989, but the stake was sold in 1992. In 1991, Vestervangen Holding replaced the founder step by step and in 1994 the industrial group Schouw \& Co. bought a quarter of the shares in Micon and later increased this stake. The group already owned a significant stake in Nordtank Energy Group, and after one year the CEO of Nordtank Energy Group took a seat on the board of Micon, heralding the fusion of the two companies in 1997 and the establishment of NEG-Micon.

Wind World was set up as a spin-off from the original Vestas in 1986. A member of the founding family of Vestas became the CEO, and equity capital was provided by an entrepreneur with domicile in London and by Danish pension funds. Wind World was stuck in a crisis in 1997. It was restructured and returned to the market as Wind World af 1997 and was finally bought by NEG-Micon in 1998. Schouw \& Co. continued to dominate NEG-Micon and it was obvious that plans were made for a takeover of Vestas Wind Systems. In 1999, NEG-Micon ran into technical problems with turbine gear boxes and suffered a crisis. The board was not informed in time and both the management and the chairman of the board were fired. If the group of owners and managers of NEG-Micon made plans for buying Vestas Wind Systems, these plans were abandoned. A change in strategy was looming, as Schouw \& Co. in 2003 also became a dominant owner of Vestas Wind Systems. The new strategy offered a platform for the group to orchestrate a takeover of NEG-Micon by Vestas Wind Systems in 2004.

Another turbine producer, which also originated from a family of blacksmiths, is Bonus Energi. It was family-owned from 1979 until it was sold to the German giant Siemens in 2004. After 2004, the company was renamed Siemens Wind Power and was organized as a division subordinated to its owner Siemens AG, but with a separate board. Finally, Danwin started as a spin-off from a shipyard (Helsingør

${ }^{5}$ The group exercised control through holding companies such as Vestas Wind Systems Holding, Vestas Wind Systems Holding II B.V. and Jopo II B.V. Vestas Wind Systems Holding, also made the new constellation of owners a crucial block holder in the Spanish turbine producer Gamesa, already when this company was established in 1993. No fusion was carried out, but, probably, the governance of the two companies was coordinated. 
Skibsværft A/S), when the shipyard was closed in 1985. One person provided the whole capital and this owner control did not change until Danwin went bankrupt and exited in 1992.

Table 3 sums up the exits and the buyouts from these historical records.

Table 3. Buyouts and exits by year. Numbers refer to companies in table 1

\begin{tabular}{lll}
\hline Year & Exits & Buyouts $^{6}$ \\
\hline 1986 & & $1,3,5,10$ \\
1987 & & 6 \\
1989 & & 2,5 \\
1990 & & 3,8 \\
1991 & & 5,12 \\
1992 & 13 & \\
1994 & & $2,5,7$ \\
1997 & & 5,7 \\
1998 & & 2,8 \\
2002 & 11 & \\
2003 & & 2 \\
2004 & & 4,10 \\
\hline
\end{tabular}

Source: CVR at the Danish Commerce and Companies Agency

\subsection{Enterprise Aspects of Governing Wind Turbine Production}

At the early stage of the industrial life cycle, before 1992 when the companies still are young and governed by a small number of founders, buyouts seem to depend on conflicts among the founders. Sometimes one of the founders tries to consolidate his or her control over the company causing others to leave. The internal technological resources are still scarce and the governance system is relatively closed to external investors, whose concern and influence on the technological competencies of the companies are limited. At this stage, the companies hire few engineers.

In 1990, Vestas Wind Systems introduced wind turbine concept B when owners and managers of the company also orchestrated a takeover of Danish Wind Technology. It is tempting to conclude that the turbine concept B was developed by Danish Wind Technology. Owners of Vestas Wind Systems were worried about the future growth potential, but instead of supporting a strategy for the development of the new technology in-house, they presumably assured that the technology needed was acquired externally. One year before the listing on the Copenhagen Stock Exchange, Vestas Wind Systems introduced the new turbine concept C in 1997, likely to appeal to investors. In the same year, Micon and Nordtank Energy Group merged, but this process started with a buyout in 1994, in which a constellation of owners, already having a stake in Nordtank Energy Group, increased its control over Micon. The fusion between the two companies was carried out and NEG-Micon was established when Vestas Wind Systems launched turbine concept $\mathrm{C}$ in 1997. The new company succeeded launching turbine concept $\mathrm{C}$ in 2002 (cf. table 3).

Case evidence of buyouts provides support for the emerging theory that shareholders pay regards to the development of the internal resources and the growth potential when making investment decisions, which are motivated by deliberations on competition. Buyouts are sometimes carried out one or two years before a significant takeover, which suggests that there are expectations among shareholders regarding forthcoming takeovers inducing the need for preparations. According to the theory taking shape, the adaptation of the growth potential to the competitive situation of companies is a vital factor determining owners' investments in companies. Empirical evidence showing that the number of engineers employed increases significantly during these preparations supports this theory. Allen and Gale (1998) consider dynamic competition in product markets orchestrated by entrepreneurial management teams as a particular corporate control mechanism. They consider this mechanism as being different from corporate 
governance that rely on outside owners. Our empirical evidence of buyouts suggests something else, leading us to conclude that owners interfere to satisfy companies' need to adapt to dynamic competition. This interference escalated after the buyout of Danish Wind technology by Vestas Wind Systems, which marked the beginning of a new competitive stage of the industrial life cycle.

Empirical evidence from this study, that owners' concern about innovations is growing after some time, is contrary to scholars who argue that a dominant design appears early in the industrial life cycle and the number of innovations decreases afterwards (Kaplan et. al. 2009), (Klepper 1996), (Cohen \& Klepper 1992), (Gort \& Klepper 1982). The type A concept, which has been referred to as 'the Danish concept', was established early and widely used. However, the development of the wind turbine concepts $\mathrm{B}, \mathrm{C}$ and D took place later on, suggesting that innovation strategies continue to be important. The theory supported by the current study is more in accordance with Yamamora et al. (2005) showing that the number of qualitative product improvements increases at later stages of the life cycle. The probability of survival is low for firms that continue to specialize in producing the type A concept. Two of them exited from the market and two were taken over by other firms.

\subsection{Coevolution of Governance and Competition}

While the previous discussion highlights how owners carefully consider business value of technological competencies before investing in companies, there is not yet a satisfactory theory about the impact on corporate governance institutions. As advocates of the team production theory of the firm have discussed, competencies are protected by the board, which is the governance institution responsible for maximizing the wealth-creating potential of companies (Machold et. al. 2011), (Huse \& Gabrielsson 2008), (Blair 1998). However, little emphasis has been put on how boards are adjusted to accommodate the need for developing internal resources and growth opportunities when competition changes over the industrial life cycle. Four board structures were developed to examine this topic (section 3.2). Information about buyouts in table 3 is used to examine changes in the boards observed by comparisons of the board structure before and after buyouts. Table 4 shows the changes for all observations in table 3. Except for boards of type D, there are only three observations of buyouts (1986 (1), 1987(6) and 1989(2)) comprising boards that do not qualify for the lowest ranked type A structure.

Before the technological race was initiated by Vestas Wind Systems launching turbine concept B in 1990, owners' concern about, and influence on, technological competencies are limited. Empirical evidence of board structures suggests that small boards (type D) were common and usually retained after a buyout. At this early stage of the industrial life cycle, the owners primarily view boards from an accountability perspective. Thus, small boards usually include an economist or a lawyer with a university degree suggesting that wind turbine firms had board directors with high competencies in business administration early in their lifetime ${ }^{7,8}$. After the technological race started in 1990 , changes in the composition of boards after buyouts were common and engineers with an academic degree were invited to sit on the board.

We try to argue, and will verify empirically, that changes in the board over time tend to improve the conversational exchange to better suit owners' concern about technological competition. For this purpose, we use a proxy of efficient conversational exchange, which is defined using the four board structures in section 3.2. To serve our purposes, we choose a proxy that represents the benefits of having directors from various educational groups at the board as well as advantages of a representation for each group above a critical threshold. Board structures $\mathrm{B}$ and $\mathrm{C}$ have these properties.

According to table 4, board structure B, which facilitates efficient conversational exchange between directors who hold business degrees and directors holding degrees in engineering, becomes the dominant board type. Data suggests that owner-interests in high technological quality are not expressed as claims to specific board structures, but these structures are indirect effects of the shareholders' concern about innovation management. Hence, the empirical evidence shows that engineers begin to have chairs on the

\footnotetext{
${ }^{7}$ When this competence was lacking on one of the boards, the founding father was replaced by the CEO, who holds an academic degree in business administration.

${ }^{8}$ High technological competencies could not replace these competencies as suggested by Danwin. Danwin exited in spite of the fact that one of its three directors had a university degree in engineering. This firm is the only one lacking a director with higher education in business administration.
} 
Table 4. Board structures before and after buyouts (exits).

\begin{tabular}{|c|c|c|c|c|c|c|c|c|c|}
\hline \multirow[t]{2}{*}{ Incident } & \multicolumn{4}{|c|}{$\begin{array}{c}\text { Board structure } \\
\text { Before }^{9}\end{array}$} & \multicolumn{3}{|c|}{$\begin{array}{l}\text { Board structure } \\
\text { After }^{10}\end{array}$} & \multirow[b]{2}{*}{$\mathrm{C}$} & \multirow[b]{2}{*}{ D } \\
\hline & $\mathbf{A}$ & B & C & D & & $\mathbf{A}$ & B & & \\
\hline 1986(1) & - & $\mathrm{x}$ & - & - & & - & - & - & - \\
\hline $1986(3)$ & - & $\mathrm{x}$ & $\mathrm{x}$ & - & & - & $\mathrm{x}$ & - & - \\
\hline $1986(5)$ & - & - & - & $\mathrm{x}$ & & - & $\mathrm{x}$ & - & - \\
\hline 1986(10) & - & - & - & $\mathrm{x}$ & & - & - & - & $\mathrm{x}$ \\
\hline 1987(6) & - & - & - & - & & - & - & - & - \\
\hline $1989(2)$ & - & - & - & - & & - & $\mathrm{x}$ & $\mathrm{x}$ & - \\
\hline $1989(5)$ & - & - & - & $\mathrm{x}$ & & - & - & - & $\mathrm{x}$ \\
\hline 1990(3) & - & - & $\mathrm{x}$ & - & & - & $\mathrm{x}$ & $\mathrm{x}$ & - \\
\hline $1990(8)$ & - & - & - & $\mathrm{x}$ & & - & - & - & $\mathrm{x}$ \\
\hline 1991(5) & - & - & - & $\mathrm{x}$ & & - & - & - & $\mathrm{x}$ \\
\hline 1991(12) & - & $\mathrm{x}$ & - & - & & - & $\mathrm{x}$ & - & - \\
\hline 1992(13) & - & - & - & $\mathrm{x}$ & Exit & - & - & - & - \\
\hline $1994(2)$ & - & $\mathrm{x}$ & $\mathrm{x}$ & - & & - & $\mathrm{x}$ & $\mathrm{x}$ & - \\
\hline $1994(5)$ & - & - & - & $\mathrm{x}$ & & - & $\mathrm{x}$ & - & - \\
\hline $1994(7)$ & - & - & - & $\mathrm{x}$ & & - & $\mathrm{x}$ & - & - \\
\hline $1997(5)$ & $\mathrm{x}$ & - & - & - & & - & $\mathrm{x}$ & - & - \\
\hline $1997(7)$ & $\mathrm{x}$ & - & - & - & & - & $\mathrm{x}$ & - & - \\
\hline $1998(2)$ & - & $\mathrm{x}$ & $\mathrm{x}$ & - & & - & $\mathrm{x}$ & - & - \\
\hline 1998(8) & - & - & - & $\mathrm{x}$ & & - & $\mathrm{x}$ & - & - \\
\hline 2002(11) & - & $\mathrm{x}$ & - & - & Exit & - & - & - & - \\
\hline $2003(2)$ & - & $\mathrm{x}$ & - & - & & - & $\mathrm{x}$ & - & - \\
\hline $2004(4)$ & - & $\mathrm{x}$ & - & - & & - & $\mathrm{x}$ & $\mathrm{x}$ & - \\
\hline 2004(10) & - & - & - & $\mathrm{x}$ & & - & - & - & $\mathrm{x}$ \\
\hline
\end{tabular}

Source: Questionnaire, CVR at the Danish Commerce and Companies Agency

board after the number of engineers involved in R\&D has begun to grow. In effect, board discussions are extended to encompass issues on technological designs (which are difficult to address unless there are competent engineers on the board). Top-ranking boards, meeting the conditions for moderate specialization (type C), were only found for Vestas Wind Systems and Danish Wind Technology ${ }^{11}$. Table 4 shows only one occasion when a type $\mathrm{C}$ structure cannot be considered as superior to a type B (conditions for a B type structure are not fulfilled): before the buyout 1990(3). No surprise, then, that the board was changed after the buyout into a top-ranked type $\mathrm{C}$ board .

The theory that emerges from case evidence suggests, when the industrial life-cycle advances, boards develop towards structures representing diverse stakeholders (cf. (Huse \& Gabrielsson 2008) and (Blair 1998)). This result challenges dominant theories that a prominent design and a routinized technological regime crystallize after some time (see (Klepper 1996), (Cohen \& Klepper 1992), (Gort \& Klepper 1982)). Since a dominant design increases the possibilities for firm growth, the demand for financing increases, which cannot be satisfied unless corporate control moves from insiders to independent, external directors (see Clark (2007)). The pattern that appears from our study is slightly different as it suggests that innovative activity continues to be important even at later stages of the life cycle. The most important long term board structure found in our study agrees with the process-oriented boardroom culture suggested by Huse and Gabrielsson (2008): diverse knowledge views are represented in board discussions that involve engineers and include discussions about technological designs.

\footnotetext{
11 This is the highest ranked board structure in a perfect hierarchy (educationally diversified and moderately specialised). Only for a short period immediately after Vestas Wind Systems was listed on the Copenhagen stock exchange in 1998, the condition for moderate specialisation was not fulfilled.
} 


\subsection{The importance of places}

Over time, the geographical spread of the directors, and/or the distance between the centre of their residences and the company, increase for a majority of the turbine producers $\left(D_{1}\right.$ and $D_{2}$ in section 3.2 increase as time passes) (table 5). This geographical evolution can be interpreted as adaptations to the competitive environment. Competent boards can only be recruited within a certain distance from the headquarter. Vestas/Vestas Wind Systems and NEG-Micon are the only turbine producers, besides Siemens Wind Power, that have developed turbine concepts B and C, which are more advanced than the conventional design A. At the same time, they have a high $\frac{D_{1}}{D_{2}}$ value suggesting that those in control of the companies assign a high value to board members' proximity to the source of technological knowledge. This value was high already from the beginning and is still high at later stages of the industrial life cycle. Some turbine producers show low $\frac{D_{1}}{D_{2}}$ values (Wind World, Bonus Energi, Wincon West Wind, and Danwin, which have all exited or been taken over by another firm) suggesting that the accountability perspective has a higher priority. The importance of this perspective does not increase at later stages of the life cycle. It should be noted that turbine producers with a low $\frac{D_{1}}{D_{2}}$ value have either been outcompeted or have been taken over by other turbine producers.

Table 5. $D_{1}, D_{2}$ and $\underline{D}_{1}$ by company. Distances in $\mathrm{km}$ and for the whole lifetime.

\begin{tabular}{|c|c|c|c|c|c|c|}
\hline Current firms & Distances & $\begin{array}{l}\text { Intermediate } \\
\text { period }\end{array}$ & Beginning $^{12}$ & End $^{13}$ & $\frac{D_{1}}{D_{2}} B e g$ & $\frac{D_{1}}{D_{2}}$ End \\
\hline Vestas/Vestas Wind & $D_{1}$ & $4-126$ & 4 & 100 & & \\
\hline Systems & $D_{2}$ & $3-179$ & 3 & 39 & 1.33 & 2.56 \\
\hline Danish Wind & $D_{1}$ & $89-97$ & 100 & 85 & & \\
\hline Technology & $D_{2}$ & $53-77$ & 110 & 123 & 0.91 & 0.69 \\
\hline \multirow[t]{2}{*}{ NEG-Micon } & $D_{1}$ & $/{ }^{14}$ & 71 & 73 & & \\
\hline & $D_{2}$ & $/^{15}$ & 38 & 42 & 1.87 & 1.74 \\
\hline \multirow[t]{2}{*}{ Micon } & $D_{1}$ & $39-76$ & 12 & 68 & & \\
\hline & $D_{2}$ & $33-104$ & 7 & 75 & 1.71 & 0.91 \\
\hline Nordtank/Nordtank & $D_{1}$ & $3-60$ & 3 & 64 & & \\
\hline Energy Group & $D_{2}$ & $9-16$ & 9 & 20 & 0.33 & 3.20 \\
\hline \multirow[t]{2}{*}{ Wind World } & $D_{1}$ & 0 & 16 & 0 & & \\
\hline & $D_{2}$ & 90 & 74 & 90 & 0.22 & 0 \\
\hline \multicolumn{7}{|l|}{ Siemens Wind } \\
\hline \multicolumn{7}{|l|}{ Power $^{16}$} \\
\hline \multirow[t]{2}{*}{ Bonus Energi } & $D_{1}$ & 4 & 4 & 4 & & \\
\hline & $D_{2}$ & 6 & 6 & 6 & 0.67 & 0.67 \\
\hline \multirow[t]{2}{*}{ Wincon West Wind } & $D_{1}$ & $55-62$ & 61 & 67 & & \\
\hline & $D_{2}$ & $102-103$ & 103 & 102 & 0.59 & 0.66 \\
\hline \multirow[t]{2}{*}{ Wincon } & $D_{1}$ & $/^{17}$ & 20 & 20 & & \\
\hline & $D_{2}$ & $/^{18}$ & 11 & 11 & 1.82 & 1.82 \\
\hline \multirow[t]{2}{*}{ Danwin } & $D_{1}$ & 13 & 13 & 15 & & \\
\hline & $D_{2}$ & 19 & 19 & 16 & 0.68 & 0.94 \\
\hline
\end{tabular}

Source: Questionnaire 
Now, we take the additional step to theorize that high $\frac{D_{1}}{D_{2}}$ values depend on the fact that inside directors living close to the headquarters are vital for efficient communication with the technical personnel. That is, these directors are in a favorable position to motivate the stakeholders to stay in the company and create more value. Inside directors are also capable of taking advantage of agglomeration factors such as concentrations of place-based knowledge that is immobile over long distances and, therefore, difficult to access for independent, external directors. Case evidence suggests that innovation management continues to be an important aspect of owner control also at later stages of the industrial life cycle. Owners recruit directors where the value-creating stakeholders live at later stages of the cycle as the supply of innovative opportunities are significant at these stages of the industrial life cycle. In relying on Cohen and Levinthal (1989), we conclude, as the return on absorptive capability for technology is high at the late stage, it is in the interest of the financiers of companies that boards invest in R\&D to increase this capability. A necessary condition is that the board of directors maintains excellent communication with the chief engineers. Communication between the boardroom and the chief engineers is improved if some directors belong to the same professional communities as the engineers who live in the surrounding region.

Theory emerging from this study suggests that board work can gain from social capital in local communities of engineers where trust relations promote social learning. Probably, the yields of the social capital help to attract financiers; even if a part hereof must be allocated to compensate the skilled workers for not abandoning the firm. The gains increase if board members are recruited from the same region as the company attracts and generates knowledge, where the directors share social networks that provide dense information flows. An additional condition is the presence of a substantial number of companies in the region that share the same pool of knowledge. Yet, to make full use of social ties and trust relationships, $D_{1}$ and $D_{2}$ cannot be very large. It makes sense that the use of social capital for obtaining knowledge from the pool is optimized if the location of the residencies of the directors coincides with the labour market area of the technical personnel. The advantage of coincidence increases if there are directors with education in engineering, who belong to the same professional communities as the technical personal.

It is likely that Vestas Wind Systems has exceeded the critical distance for full use of the social capital, while in the case of Wincon the distance has been too small (see table 5). Indeed, Bonus Energi had a low $\frac{D_{1}}{D_{2}}$ value, and small $D_{1}$ and $D_{2}$. The inability to gain from social capital may have prevented the engineers at Bonus Energi from developing the type D turbine concept before the takeover by Siemens. The realistic view is that the development of this advanced concept demands specific capabilities in the area of power electronics that Siemens has. Siemens recognized that part of its core competencies could be applied to wind turbines and Bonus Energi became the target of a diversification in related industries where pre-entry experience of an entrant influences the evolution of an industry (Bauenstorf 2006). With the introduction of the type D turbine concept, the technological foundation of Bonus Energi changed, which will likely cut the technological ties with the place where the company was headquartered. It seems, in the case of diversification in related industries, as if the technological capabilities of the target become dependent on external sources, and the corporate governance system becomes dependent on outside monitoring, which altogether reduces the advantages of recruiting board directors locally.

For companies with foreign owners, the distance between Danish board members decreased immediately after control was transferred to the foreigners, which supports the idea that remote owners are attracted if members of the corporate board are well acquainted with local conditions. This pattern does not apply to Siemens Wind Power after Siemens' buyout of Bonus Energi. Siemens acquired a turbine producer with a board of directors living in close proximity to the factory. Nevertheless, Siemens replaced them with external board members. One conclusion is that Siemen's aspiration for technological leadership effectively marginalized the board, which lost its role as strategic adviser. In this situation, the local affiliation of board members is of minor importance.

\section{Discussion and Conclusion}

Our objective is to examine how corporate governance changes over time when properties of the geographic location commit companies to certain governance structures. Kogut and Walker (2001) examine German ownership groups originating from regional networks, where local banks have an important role. These groups, which are robust and resist competitive pressure, emerge from micro-behavior by investors acting strategically (Kogut 2012). While their findings that strategizing actors are regional or local rest on a solid 
foundation, the proposal that governance is resistant to changes need to be revised when technological competition influences strategic actions. The case study of the Danish wind turbine production is a story about how ownership groups are driven by technological competition. The empirical evidence is a number of buyouts orchestrated by groups of owners that initiated a technological race in the beginning of 1990s. Empirical evidence shows that the number of engineers employed increases significantly because of these buyouts (section 4.2). One consequence of the shareholders concern about innovation management was a change in board structures as engineers began to have chairs on the boards making the conversational exchange more efficient (section 4.3).

It can be argued using case evidence that after the initial stage of the industrial life cycle, when the internal technological resources are still scarce, technological competition is intensified. Board structures change from serving accountability functions towards fulfilling enterprise aspects and to represent diverse stakeholders. The new governance resembles the process-oriented boardroom cultures discussed by Huse and Gabrielsson (2008) that facilitate efficient conversational exchange.

There is reason to believe that owners encouraging changes in governance also become adept at adopting new board structures. Instead, according to a perspective taking shape in this article, the shareholders and managers have significant problems in relating to information about the new technology, which makes the organizing of the governance difficult. The case of wind turbine production provides examples of what Kogut and Walker (2001) call "technological beliefs" that spur owners and managements to prepare companies for forthcoming technological competition. Evidence shows periods before significant buyouts in which the number of engineers employed increases to fulfill beliefs about high corporate technological quality. From this emerging perspective, teams of owners and managers have paramount problems in understanding technological information they receive, which influences the decisions about appropriate governance structures for suitable innovation management. The case study reveals board structures that provide for communicative exchange between directors, who hold degrees in economics and directors holding degrees in engineering. Yet, they appear only after the number of engineers involved in R\&D has begun to grow, and the need of engineers in the boardrooms to deal with technological information arises.

Awareness about the importance of knowledge conditions of technology that influence corporate governance is raised in studies by Reid and Smith (2008), Audretsch and Fritsch (2002) and Audretsch (1995). Further extension of this perspective on governance in this case study looks promising. It leads to a better understanding of the underlying mechanism of the "small worlds" of stratigizing actors in Kogut and Walker (2001)and Kogut (2012). Although the case evidence shows that governance structures are sensitive to changes, the geographic affiliations of the "small worlds" turned out to be resistant to changes. The question about why the geographic affiliation is resistant can be answered using ideas from the team production theory of the firm about boards as coordinating bodies responsible for maximizing the wealth-creating potential of companies (Machold et. al. 2011), (Huse \& Gabrielsson 2008) and (Blair 1998). Maximization requires efficient communicative exchange in the boardrooms about the representation and the protection of a diverse set of stakeholders in and around the company. This communication is associated with adverse (technological) knowledge conditions as highlighted in this article. It turns out that ownership groups respond to these conditions by recruiting directors in places, where the value-creating technical workers live. The perspective taking shape that board work can take advantage of directors living in proximity to the place where the company generates and attracts technological knowledge is supported by established thinking in geography. According to this thinking technological knowledge is immobile over long distances and is often personified by employees who move between working places in a regional labour market. The latter knowledge condition implies that firm-specific knowledge can be used by several companies located to the same place (Asheim \& Gertler 2006; Fosfuri \& Rønde 2004; Werker \& Athreye 2004).

For wind turbine production, ownership groups have sometimes neglected the importance of board members' proximity to locations where companies generate or obtain technological knowledge, but in these cases the companies have either been outcompeted or have been taken over by other turbine producers. Yet, emerging theory reveals that the need of coincidence between the place, where the company mobilizes technological knowledge, and the place of residence of the board members varies with type of ownership group. Coincidence is particularly common among companies with foreign owners. However, in case of a new owner has specific pre-entry experience, such as Siemens that took over Bonus Energi, the 
technological ties between a target company and a place can be cut creating a dependency on outside control.

This study also contributes to prior research challenging the accountability perspective on corporate governance (Filatotchev \& Wright 2005; Rajan \& Zingales 2000; Short et. al. 1999). Our observations of buyouts support the theory that innovation management plays a vital role for owners investing in a company. With its focus on buyouts, the case study also challenges an idea by Allen and Gale (1998) that outside owners are passive with regard to competition in the product market, which they consider as orchestrated by entrepreneurial management teams. Our empirical evidence suggests that owners are active and investments are motivated by deliberations on competition. This finding also casts light on how time influences ties between the geographic location and companies' governance structures. According to case evidence investor concern about innovation management is less significant at the earlier stages of the industrial life cycle (the accountability perspective of corporate governance dominates at these stages). Therefore, we propose an idea that owners assign high value to board members' proximity to firm-specific knowledge after some time of the life cycle has elapsed. The perspective on the time pattern taking shape supports research by Yamamura et al. (2005) showing significant technological changes at later stages of the life cycle. This perspective challenges views that a dominant technological design appears early, while the number of innovations decreases later on (Kaplan et. al. 2009), (Klepper 1996), (Cohen \& Klepper 1992), (Gort \& Klepper 1982). From the theory emerging in this article, it is evident that innovation management is an important aspect of owner control at the late stage of the industrial life cycle. Under these circumstances owners request a close relationship between board members and the place where the firm-specific knowledge is developed, which questions the idea that corporate control, due to conditions of financing, moves from insiders to external, independent directors (see Clark (2007)).

The findings of the current study are summarized in figure 1. It shows how governance changes over the industrial life cycle with intensified technological competition as a critical watershed. Even if the board members seem to be recruited in the neighborhood of the companies irrespectively competitive stage, the watershed implies a change in requirements to board composition and a corresponding change in the board-place connections. The study raises new interesting questions, but it also has some shortcomings to be addressed in future research. While we explored how changes in corporate governance are related to geographic factors, we concentrated on board structures but neglected other governance institutions. For instance, case evidence suggests that ownership structure can be crucial in answering the research question, firstly because this institution probably affects the role of geographic proximity. Secondly, type of ownership structure impacts the role of the board, sometimes by cutting its ties with a certain place. Another reason for why the findings may not be exhaustive is related to limitations of the data. It is true that a single-case study is particularly suitable for illuminating and extending the logical relationships between innovations, places and the evolution of corporate governance, but possibilities for generalizability are reduced. Further research could examine multiple industries that rely on different types of technology. Such examinations increase the understanding of to what extent the results depend on companies' rate of human capital accumulation, which varies across industries.

\section{References}

1. Aglietta, M, Rebérioux, A (2005), Corporate Governance Adrift. A critique of shareholder value, Cheltenham

2. Allen, F, Gale, D (1998), Corporate governance and competition, Paper presented at a conference on corporate governance in Barcelona, Spain, October 1998

3. Asheim, B, Gertler, M (2006), The geography of innovation: Regional Innovation Systems (in Fagerberg, J, Mowery, D, Nelson, R (eds), The Oxford handbook of innovation), Oxford

4. Audretsch, D, Fritsch, M (2002), Growth regimes over time and space, Regional Studies Vol. 36.2

5. Audretsch, D, Keilbach, M, Lehmann, E (2006), Entrepreneurship and economic growth, Oxford

6. Audretsch, D (1995), Innovation and industry evolution, Cambridge

7. Bauenstorf, G (2006), How useful is generalized Darwinism as a framework to study competition and industrial evolution? Journal of Evolutionary Economics 16: 511-527

8. Becker, G (1964), Human Capital: A Theoretical and Empirical Analysis with Special Reference to Education, Chicago 


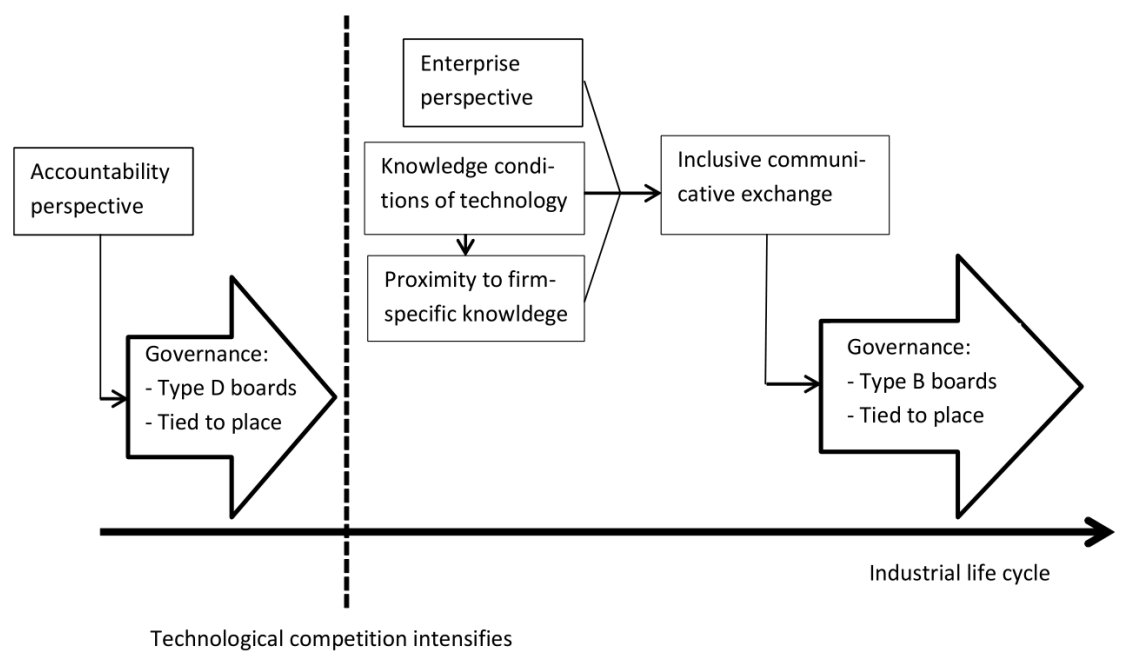

Figure 1. Towards a model of the impact of places on corporate governance.

9. Blair, M (1998), For whom should corporations be run?: An economic rationale for stakeholder management, Long Range Planning, 31(2):195 - 200

10. Bottazzia, L, Da Rin, M, Hellmann, T (2009), What is the role of legal systems in financial intermediation? Theory and evidence, Journal of Financial Intermediation, Volume 18, Issue 4, pp 559-598

11. Brenner, T, Fornahl, D (2008), Regional Path-Dependence in Start-up Activity, Papers in Evolutionary Economic Geography (PEEG) 0812, Utrecht University

12. Clark, T (2007), International corporate governance: a comparative approach, New York

13. Cohen, W, Klepper, S (1992), The Anatomy of industry R\&D intensity distributions, American Economic Review, Vol. 82, No 4, 773 - 799

14. Cohen, W, Levinthal, D (1989), Innovation and Learning: The Two Faces of R\&D, The Economic Journal, Vol. 99, No. 397

15. Dicken, P (2000), Places and flows: Situating International Investment (in Clark, G, Feldman M P, Gertler, M S (eds.), The Oxford Handbook of Economic Geography), Oxford

16. Eisenhardt, K, Graebner, M (2007), Theory Building from Cases: Opportunities and Challenges, Academy of Management Journal, Vol. 50, No. 1, 25-32

17. Estevez-Abe, M, Iversen, T, Soskice, D (2001), Social protection and the formation of skills: a reinterpretation of the welfare state (in Hall, P, Soskice, D (eds.), Varieties of capitalism. The institutional foundations of comparative advantages), Oxford

18. Fama, E, Jensen, M (1983), Separation of Ownership and Control, Journal of Law and Economics, $26: 301-325$

19. Filatotchev, I, Wright, M (2005), The corporate governance life cycle (in Filatotchev, I, Wright, M (eds), The life cycle of corporate governance), Cheltenham

20. Fosfuri, A, Rønde, T (2004), High-tech Clusters, Technology Spillovers and Trade Secret Laws, International Journal of Industrial Organisation, Volume 22, Issue 1, pp. 45-65

21. Gort, M, Klepper, S (1982), Time paths in the diffusion of product innovations, The Economic Journal vol $92 \mathrm{nr} 367$ 630-653

22. Hansen, A, Hansen, L (2006), Wind turbine concept market penetration over 10 years (1995-2004), Wind Energy DOI: 10.1002/we

23. Hellman,T, Puri, M (2000), The interaction between product market and financing strategy: the role of venture capital, Review of Financial Studies, Volume 13, Issue 4, pp. 959 - 984

24. Huse, M, Gabrielsson, J (2008), Boards of directors and corporate innovation: An empirical investigation from a team production approach, Paper presented at EURAM Annual Conference, May 14-17, Ljubljana, Slovenia. 
25. Johnson, S G, Schnatterly, K, Hill, A D (2012), Board Composition Beyond Independence: Social Capital, Human Capital, and Demographics, Journal of Mangement, DOI: 10.1177/ 0149206312463938

26. Kaplan, S, Sensoy, B, Strömberg, P (2009), Should investors bet on the jockey or the horse? Evidence from the evolution of firms from early business plans to public companies, The Journal of Finance, Vol LXIV, no $1,75-115$

27. Kaufman, A, Englander, E (2005), A team production model of corporate governance, Academy of Management Executive, 19(3):9-22

28. Khanagha, S, Volberda, H, Sidhu, J, Oshri, I (2013), Management Innovation and Adoption of Emerging Technologies: The Case of Cloud Computing, European Management Review, Vol. 10, 51 $-67$

29. Kirchmaier, T, Kollo, M G (2006), The role of prestige and networks in outside director appointments, work in progress, Financial Markets Group, London School of Economics

30. Klepper, S (1996), Entry, exit, growth and innovation over the product life cycle, The American Economic Review, Vol. 86, No 3, 562 - 583

31. Kogut, B (2012), Business Groups and Financial Markets as Emergent Phenomena (in Cetina, KK, Preda, A (eds), The Oxford Hanbook of Sociology of Finance), Oxford

32. Kogut, B, Walker, G (2001), The Small World of Germany and the Durability of National Networks, American Sociological Review, Vol. 66, No. 3, 317-335

33. La Porta, R, Lopez-de Silanes, F, Schleifer, A, Vishny, R (2000), Investor protection and corporate governance, Journal of Financial Economics 58, Issues 1-2, 3-27

34. La Porta, R, Lopez-de-Silanes, F, Shleifer, A,Vishny, R (1999), Investor Protection and Corporate Valuation, Working Paper 7403, NBER Working Paper Series

35. Lerner, J, Strömberg, P, Sørensen, M (2008), Private equity and long-run investment: the case of innovation (in the Global Economic Impact of Private Equity Report), The World Economic Forum

36. Machold, S, Huse, M, Alessandro, M, Nordqvist, M (2011), Board leadership and strategy involvement in small firms: A team production approach, Corporate Governance: An International Review, 19(4): $368-383$

37. Rajan, R G, Zingales, L (2000), The governance of the new enterprise (in Vives, X (ed), Corporate governance. Theoretical and empirical perspectives), Cambridge

38. Reid, G, Smith, J (2008), Why is it so hard to value intangibles? Evidence from investments in high-technology start-ups, CRIEFF Discussion Paper Number 0806, University of St. Andrews

39. Roe, M (2005), The political roots of American corporate finance (in Chew, D, Gillan, S (eds.), Corporate governance at the crossroads), New York

40. Short, H, Keasey, K, Wright, M, Hull, A (1999), Corporate governance: from accountability to enterprise, Accounting and Business Research vol. 29 no 4 pp 337-352

41. Sinani, E, Stafsudd, A, Thomsen S, Edling, C, Randøy, T (2008), Corporate governance in Scandinavia: comparing networks and formal institutions, European Management Review, 5:27-40

42. Toms, S, Filatotchev, I (2005), Corporate governance and financial constraints on strategic turnarounds (in Filatotchev, I, Wright, M (eds), The life cycle of corporate governance), Cheltenham

43. Werker, C, Athreye, S (2004), Marshall's disciples: knowledge and innovation driving regional economic development and growth, Journal of Evolutionary Economics 14: 505-523

44. Yamamura, E, Sonobe, T, Otsuka, K (2005), Time path in innovation, imitation, and growth: the case of the motorcycle industry in postwar Japan, Journal of Evolutionary Economics 15: 169 - 186

45. Zahra, S, Hayton, J (2005), Organisational life cycle transitions and their consequences for the governance of entrepreneurial firms: an analysis of start-up and andolescent high-technology new ventures (in Filatotchev, I, Wright, M (eds), The life cycle of corporate governance), Cheltenham

46. Zingales, L (2000), In search of new foundations, Journal of Finance 55(4):1623-53 